\title{
Abstract \\ Throwing Power of Embedded Anodes for the Galvanic Cathodic Protection of Steel in Concrete ${ }^{+}$
}

\author{
Bjorn Van Belleghem *(D), Tim Soetens and Mathias Maes \\ SANACON, Spin-Off Company Magnel-Vandepitte Laboratory for Structural Engineering and Building \\ Materials, Nijverheidsweg 1/A, B-9820 Merelbeke, Belgium; tim.soetens@sanacon.be (T.S.); \\ mathias.maes@sanacon.be (M.M.) \\ * Correspondence: bjorn.vanbelleghem@sanacon.be; Tel.: +32-478-511-876 \\ + Presented at the First Corrosion and Materials Degradation Web Conference, 17-19 May 2021; Available online: \\ https://cmdwc2021.sciforum.net/.
}

check for updates

Citation: Van Belleghem, B.; Soetens, T.; Maes, M. Throwing Power of Embedded Anodes for the Galvanic Cathodic Protection of Steel in Concrete. Mater. Proc. 2021, 6, 17. https://doi.org/10.3390/CMDWC 2021-09898

Academic Editor: David M. Bastidas Published: 6 May 2021

Publisher's Note: MDPI stays neutral with regard to jurisdictional claims in published maps and institutional affiliations.

Copyright: (C) 2021 by the authors Licensee MDPI, Basel, Switzerland. This article is an open access article distributed under the terms and conditions of the Creative Commons Attribution (CC BY) license (https:// creativecommons.org/licenses/by/ $4.0 /)$.

\begin{abstract}
The chloride-induced corrosion of steel reinforcement is one of the main causes of deterioration of reinforced concrete structures. Cathodic protection (CP) of steel in concrete is a widely accepted repair technique to reduce, or completely stop, reinforcement corrosion. One possible method of cathodic protection is through the use of embedded galvanic (sacrificial) anodes, consisting of a zinc metal core surrounded by a precast alkali-activated cementitious mortar. The design of a CP system based on embedded galvanic anodes is based on the required amount of zinc material and the throwing power of the anode (i.e., radius around the anode in which the steel achieves sufficient protection). In this research, the protection of steel reinforcement in concrete surrounding an embedded galvanic anode was evaluated through depolarisation measurements with internal and external reference electrodes. Based on these measurements, the throwing power of the galvanic anode was determined, taking into account the $100 \mathrm{mV}$ depolarisation criterium (cf. EN ISO 12696:2016). Additionally, the influence of the degree of chloride contamination of the concrete and relative humidity and temperature of the environment on the throwing power was evaluated. The results show a strong influence of chloride contamination on the throwing power of the galvanic anodes, in the sense that a higher chloride concentration in the concrete matrix leads to a reduction in the throwing power. This reduction can be related to the more negative potential of corroding steel reinforcement compared to passive steel, thus leading to a lower driving potential for the galvanic reaction. Especially when the chloride concentration is higher than $1 \mathrm{~m} \%$ vs. cement mass, the throwing power is greatly reduced. Additionally, it was found that a higher relative humidity (RH) of the environment (and consequently, a higher $\mathrm{RH}$ of the concrete) resulted in a higher throwing power.
\end{abstract}

Keywords: reinforcement corrosion; galvanic cathodic protection; embedded anodes; throwing power

Supplementary Materials: The conference presentation file is available at https:/ /www.mdpi.com/ article/10.3390/CMDWC2021-09898/s1.

Institutional Review Board Statement: Not applicable.

Informed Consent Statement: Not applicable. 